\title{
DOES DEFERRED TAX MEDIATE THE RELATIONSHIP BETWEEN TAX PLANNING AND EARNINGS MANAGEMENT? a. Wafaa Salah ${ }^{1}$
}

a. Lecturer of Accounting, Accounting Department, Faculty of Business Administration, Economics \& Political Sciences, The British University in Egypt, Cairo, Egypt.

\section{Abstract}

The objective of this study is to investigate the effect of deferred tax disclosed under the Egyptian Accounting Standard No. 24, income taxes and tax planning on earnings management. In addition, to investigate the role of net deferred tax liabilities as a mediator between tax planning and earnings management. This study employs a sample of 127 firms listed on the Egyptian stock exchange covering the period 2012 to 2018 ending up with 889 observations. Stratified simple random sampling technique was used to select the sample. Path analysis is employed to examine the framework of the study and analyses the indirect effect of tax planning on earnings management. In addition, Ordinary Least Square Regression is employed to calculate discretionary accrual, which is used as a proxy to earnings management. The results suggest that tax planning does not have a significant direct effect on earnings management. However, it has a significant indirect effect on earnings management through net deferred tax liabilities, which in turn has a significant direct effect on earnings management. Findings of this paper may be of interest to financial analysts and standard setters, as they highlight how tax planning and deferred tax liabilities affect the quality of accounting information.

Keywords: discretionary accrual, tax reform, accounting quality, deferred tax liabilities

$$
\begin{aligned}
& \text { مستخلص البحث: }
\end{aligned}
$$

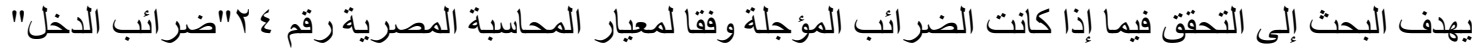

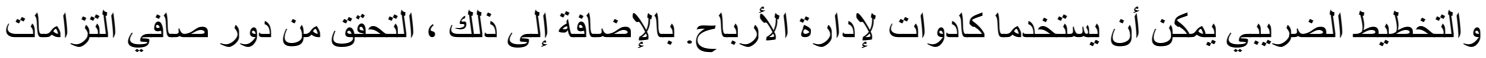

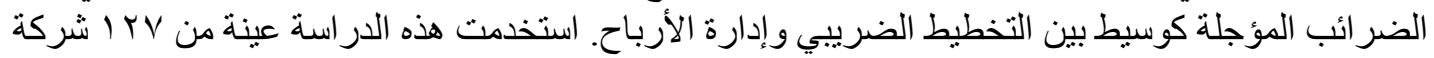

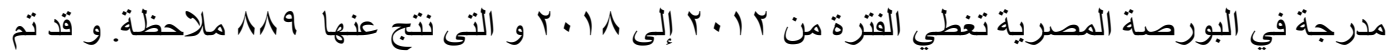

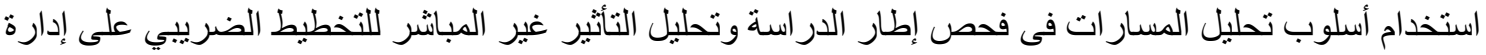

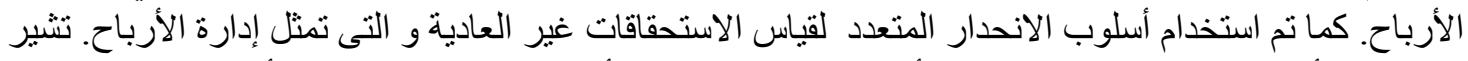

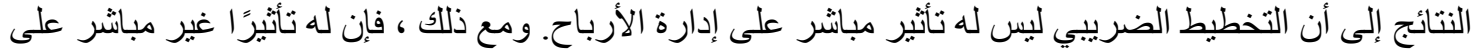

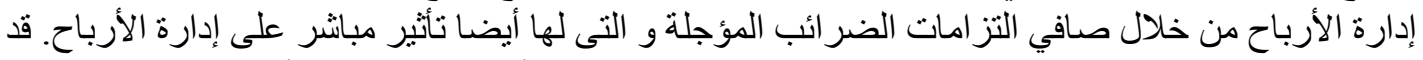

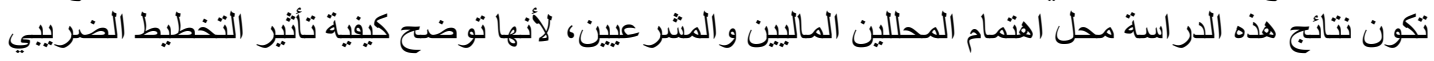

$$
\begin{aligned}
& \text { و التزامات الضر ائب المؤجلة على جودة المعلومات المنام المحاسبية . } \\
& \text { الكلمات الرئيسية: إدارة الأرباح، جودة المعلومات ، التخطيط الضريبى ، التزامات الضر ائب } \\
& \text { المؤجلة }
\end{aligned}
$$

\footnotetext{
${ }^{1}$ E-mail address: wafaa.salah@bue.edu.eg
} 


\section{Introduction}

Corporate taxation is considered one of the main sources of the Egyptian Government's revenue. The tax rate average is 21.92 percent from 2006 to 2018 , reaching a high of 25 percent in 2012 and a low of 20 percent in 2007. The aim of tax reporting is quite different from financial reporting. While the aim of taxation is to collect taxes as high as possible to ensure continuous revenue for the government budget, the aim of financial reporting is to provide insight into the firm underlying economic position to its present and potential users for making rational decisions(Gaynor, Kelton, Mercer, Yohn, \& Theory, 2016). Hence, managers are allowed by accounting standards to use accruals to enhance resource allocation and reflect true economic situation. This results in book-tax differences, which is the difference between accounting income to taxable income. According to Habanec and Bohušová (2017), book-tax differences may be caused by capital market irregularity, earnings management, or income tax accounting. Similarly, Puspitasari and Muktiyanto (2018) state that taxation is considered one of the motivators for earnings management; affecting income to reduce tax expenses in the following year.

Some managers misuse the flexibility provided by accounting standards to manipulate tax for accomplishing their personal earnings objectives which might affect the country welfare (Lee, Vetter, Williams, \& Research, 2015; Mulyadi, Anwar, \& Sciences, 2015). The accounting scandals like Enron, WorldCom showed that managers are able to manipulate earnings in the way they plan. This requires from the researchers around the world to conduct more investigation with respect to proxies of earnings management. Earnings management is defined in several different ways. One of the popular definitions was given by Healy and Wahlen (1999): "Earnings management occurs when managers use judgment in financial reporting and in structuring transaction to alter reports to either mislead some stakeholders about the underlying economic performance of the company or to influence contractual outcomes that depend on reported accounting numbers". Over time, the definition includes wider activities. For instance, earnings management is defined by Walker and Research (2013) as "The use of managerial discretion over accounting choices, earnings reporting choices, and real economic decisions to influence how underlying economic events are reflected in one or more measures of earnings". According to Mulyadi et al. (2015), firms with higher growth opportunities have a higher motivation to manipulate earnings.

Although the research in earnings management has increased since 2005, however, using deferred tax and tax planning(TP) as predictors to earnings management is a new stream of research(Wang, Butterfield, \& Campbell, 2016). Managers may use deferred tax or TP to affect book income without affecting taxable income and hence recognize deferred tax. The Egyptian Accounting standard (EAS) No. 24 which is compatible with the International Accounting 
Standards(IAS) 12 required more disclosures from firms regarding deferred tax as the evidence supporting the recognition and derecognition of the deferred tax to enable financial statement users to have adequate information regarding the deferred tax. However, firms do not provide enough disclosure, which open doors for manipulation(Elassal, 2012).

A growing body of literature finds that book-tax differences were increasing throughout the late 1990s and attribute this to managers manipulating both of them to achieve high reported book income and low reported taxable income. One of the instruments used to manipulate earnings is TP(Desai \& Dharmapala, 2009; Mikova, 2014). The main objective is to reduce the tax paid to the government to report better cash flow to investors. Phillips, Pincus, and Rego (2003) claim that managers can manipulate book income without affecting booktax differences by engaging in activities that generate permanent book-tax differences or affecting the operating cash flow and hence it is difficult to detect earnings manipulation through deferred tax. This means that deferred tax cannot grasp all earnings manipulation activities and may be considered as a mean for TP. Moreover, Puspitasari and Muktiyanto (2018) find that there is a positive relationship between earnings management and the book-tax differences in the banking industry. As a result, investigating the relationship between deferred tax, $\mathrm{TP}$ and earnings management is considered an important empirical question.

Hence, the objective of this study is to investigate whether TP and net deferred tax liabilities (NDTL) are reasonable predictors for earnings management in Egypt controlling for firm size, liquidity, financial leverage, and performance. In addition, to investigate the role of NDTL as a mediator between TP and earnings management. This paper is built on the article of Ifada and Wulandari (2015) which assumes that deferred taxes and TP are significantly affecting earnings management. However, this study focuses on firms listed on the Egyptian stock market and investigates the mediating effect of NDTL.

This study contributes to the literature in three folds. First, a growing body of literature investigated the effect of TP and deferred tax on earnings management. These studies have mostly taken place in the U.S., China, Indonesia and Europe(Brummer, 2017). However, few studies investigate this issue in Egypt. Moreover, to the researcher knowledge, no empirical study used quantitative data to investigate the association between deferred taxes, TP and earnings management practices in Egypt. Thus, the results of this study contribute to the earnings management and taxation literature and practice in Egypt by providing evidence that TP and deferred tax are powerful predictors for tax-induced earnings management. Second, this study sheds light on the characteristics of firms that can mediate the relationship between TP and earnings management. Third, contradicting results of previous studies motivates to re-investigate the impact of NDTL and TP on earnings management practices. Therefore, this study adds to the comprehension of tax management in firms. 
The results of this study find that TP does not affect directly earnings management. However, it has an indirect statistically significant effect on earnings management through NDTL, which in turn has a significant direct effect on earnings management. The results of this study are consistent with the incremental usefulness of TP and deferred tax as motivators to earnings management. These results will benefit investors, analysts, researchers, government and tax authority. It may be considered an alert to the close correlation between deferred tax, TP and reported earnings, which should be taken into consideration in studying earnings management behavior, analyses of financial reports and policy setting activities. The remaining of this paper proceeds as follows: Section 2 covers the relevant literature review and hypothesis development. Section 3 presents the data, study variables, and research model, followed by Section 4, which discusses the results, and finally concludes the paper.

\section{Literature review}

The agency theory is concerned about the conflict of interest between managers (agents) and shareholders (principals). This theory assumes that the interests of principals and agents differ. Although the managers are hired to run the business in the interest of shareholders, there is a risk that they could focus on their own interest and engage in earnings management. The firm's managers try to minimize tax to reduce the tax burden which referred to as TP(Noviana Mulyani $\&$ Dewi, 2018). According to Rehman (2017), the agency theory may cause a conflict of interest between the agent and the principal that may affect the quality of reported earnings. There is a strong correlation between TP, earnings management and behavior management which is related to the agency theory(Puspitasari \& Muktiyanto, 2018). Moreover, the positive accounting theory assumes that managers can act in either efficient way to present the true economic position of the firm or opportunistic way to maximize his own interest(Walker \& Research, 2013). According to P. M. J. J. o. a. Dechow and economics (1994), earnings manipulation is considered opportunistic behavior. The positive accounting theory is considered a part of the agency theory as the positive accounting theory concerned about three agency relationship, namely: (1) between management and the owners (2) between management and creditors, and (3) between management and the government. Earnings management behavior is based on two theories, the agency theory, which describes the environment that causes earnings manipulation, and the positive accounting theory, which focuses on motivations for manipulating earnings. 


\subsection{Deferred tax and earnings management}

The EAS issued by Ministry of Investment in 2006 were prepared according to IAS issued by the International Accounting Standard Board(IASB) with few differences(Ebrahim, 2014). In addition, The Minister of Investment decision No. 110 of 2015 on the issuance of the new Egyptian Accounting Standards are compatible largely with the international accounting standards. EAS No. 24, which is compatible with IAS 12, defined temporary differences as the timing differences between pretax financial income and taxable income based on when revenue or expense are recognized. Temporary differences that cause a future tax deduction creates deferred tax asset. On the other hand, the temporary differences that cause a future tax liability create a deferred tax liability. The two main accounts that contribute to these differences are depreciable tangible assets and intangible assets (Lee et al., 2015). Deferred tax liabilities are recognized when tax expense is greater than the tax payable. This gap is caused as a result of two situations: income before tax includes some revenues recognized but not yet recognized in taxable income or expenses deducted in taxable income that is deferred for accounting purposes until later periods. Probable deferred tax liability is recognized(Chang, Herbohn, \& Tutticci, 2009). Table 1 shows some situations that cause temporary differences.

NDTL is the difference between deferred tax liabilities and deferred tax assets(Warsono, 2017). Bernard, Skinner, and Economics (1996) state that a higher difference between firms reported pre-tax financial income and taxable income shows the "red flag" for users of financial statements. This means that users of financial statements need to be careful in using such financial statements in its decision-making. Earnings management can take place by increasing the net deferred tax liabilities, which may cause higher deferred tax expenses. This is consistent with the positive accounting theory proposed by Watts and Zimmerman (1986) in which the deferred tax expense can motivate managers to manipulate earnings for tax saving. Mills and Newberry (2001) find that privately held firms suffering from financial problems tend to have greater booktax differences, which is considered a sign of earnings management. According to Phillips et al. (2003), managers may have incentives to use deferred tax to increase or decrease financial income without affecting taxable income. They found that NDTL is a good predictor for earnings manipulation by controlling the impact of changes in cash flow from operations. This may occur due to information asymmetry between shareholders. They use the deferred tax expense, as a proxy for book-tax differences. Deferred tax expense is calculated as the annual change in total NDTL. 
Accelerated depreciation is allowed for tax purposes using rates up to $50 \%$ annually for computers and software assets.

Taxpayer is allowed $30 \%$ bonus depreciation of some new assets used.

Allowances and provisions are not deductible except if actual write off of bad debts take place after taking all necessary measures to collect the debt and not before 18 months of its initial date.

Net Operating Losses allowed to be carried forward for up to 5 years. Source: Ebrahim (2014)

Firm management may use accruals to achieve two reporting purposes, namely to avoid low profits or avoid losses. Using a sample of Chinese firms, Tang (2005) investigates the power of book-tax differences in detecting earnings management. He suggested that book-tax differences can be used as a proxy for earnings manipulation. Moreover, using a sample of consumer and industrial products firms listed on Bursa, Malaysia, R. Md Noor, N. Mastuki, and Z. J. M. A. R. Aziz (2007) examine whether deferred tax liabilities is used to prevent earnings decline or loss. They find that firms use deferred tax liabilities to prevent loss. However, they were not able to find evidence that firms use deferred tax liabilities to avoid low profits. Deferred taxes are better than revenue and expense accruals in predicting when earnings management is used to avoid an earnings decline or subsequent earnings restatements(Badertscher, Phillips, Pincus, \& Rego, 2006).

Financial accounting standards allow managers to use more discretion than tax rules. Hence, lower taxable income through the creation of deferred tax liabilities may cause a reduction in the amount of current tax and may be classified as tax avoidance. This may increase the firm value when using low-risk methods to reduce tax (Hanlon \& Heitzman, 2010). Elassal (2012) investigates the impact of deferred tax assets on earnings management. He finds that Egyptian firms disclose incomplete information regarding the deferred tax to manage earnings and meet financial analysts' earnings forecasts. Additionally, Blaylock, Gaertner, and Shevlin (2015) find that there is a positive relationship between book-tax differences and earnings management. He claimed that the benefits of higher book-tax conformity are more faithfully represented financial statements with less earnings management, reduction in both tax shelters and firm compliance costs. Moreover, Ifada and Wulandari (2015) investigate the use of deferred tax expense, TP and firm size in managing taxable income instead of financial accounting income. They found that there that deferred taxes significantly affect earnings management. However, they found no significant relationship between firm size and TP on earnings management. Using a sample of 30 Egyptian listed firms, Nabil(2016) find that book-tax differences significantly affect earnings management and can be used as a model for detecting earnings manipulation. 
Additionally, using a sample of 17 firms listed on the Indonesia stock exchange for the period 2012-2015, Kusumaningrat (2017) investigate the effect of deferred tax expense, leverage, and size on earnings management. The results reveal that the deferred tax and size significantly affect earnings management. He claims that large size firms have large incentives to manipulate earnings compared to small firms to prevent sever increases in earnings to avoid high taxes. However, leverage has no significant effect on earnings management. Rathke, Rezende, Antônio, and de Moraes (2017) find that firms reporting negative earnings have significant high net deferred tax expenses. They claim that deferred tax is a suitable account for earnings management as the amount is estimated in a subjective manner based on management's judgment. This estimation allows for earnings adjustments without immediate effect on cash flow. Moreover, deferred taxes is the last account to be closed before the net income is computed which represents the last resort for managers to adjust earnings.

On the contrary side, Schrand and Wong (2003) and Phillips, Pincus, Rego, and Wan (2004) attempt to identify whether the recognition and measurement of deferred tax asset account are used to manipulate earnings but their research has led to inconclusive and contradictory results. Trisnawati and Nugraheni (2015) showed that the deferred tax expense has no effect on earnings management. Similarly, Widiatmoko and Mayangsari (2016) find that deferred tax asset has an insignificant effect on earnings management. Using a sample of 84 annually manufacturing Indonesian firm, Noviana Mulyani and Dewi (2018) find that deferred tax expenses negatively affect earnings management. Moreover, Puspitasari and Muktiyanto (2018) find that deferred tax liabilities have a lower capability to detect manipulation in earnings in both the banking and nonbanking sector.

\subsection{Tax planning and earnings management}

Nowadays, corporations depend on TP strategies as one of the financial planning tools, which helps to reduce, defer or avoid the tax burden. This takes place by identifying weaknesses and gaps in the tax laws in the country in which the firm wish to invest in. Osama (2010) viewed deferred tax as a function of TP. Nabil (2012) defines TP as an ongoing process that does not depend on a specific time or account treatment. However, it takes into consideration all administrative decisions known as tax strategies, which is used by firms as a means of predicting its financial performance. It is important to mention that there is no article under Law No. 91 issued in 2005 related to TP. The legislators were reluctant to develop an article that controls TP. However, if the tax authority discovered any treatment of TP that prevent taxpayers from paying taxes, it would not be taken into consideration as stipulated in article number 92(repeated) in law no. 53 in 2014. The article states "In determining the tax income, the tax 
effect of any transaction whose main purpose or one of its main purposes is to avoid or defer tax will be ignored".

Abdallah (2014) defines TP as a tool used to achieve the maximum benefit from tax laws and international agreements to reach the lowest tax burden possible in the light of the applicable laws, which is quite different from tax evasion, which leads to a reduction in the tax burden, but with illegal methods. Warsono (2017) defines TP as a process of choosing among various tax election methods which aim to keep tax liabilities as minimum as possible in the current year for the coming period, but still within the framework of tax regulations. TP is one form of tax management functions for reducing tax legally. According to Samir (2017), a large number of legislative amendments, the vagueness of the tax laws, the dispute over their interpretation and the desire of the creditors to reduce the tax liabilities in a legal manner lead to the increase in TP.

The positive accounting theory and TP literature have confirmed that management has strong motivations to manipulate earnings using taxes. They manage taxes to maximize shareholders wealth, reduce the political cost, and increase the firm value which will affect stock market(Phillips et al., 2003; Tang, 2005; Watts \& Zimmerman, 1986). The managers have the opportunity to manage book income upward or downward without affecting taxable income. The higher book-tax gap was attributed to aggressive TP which may be considered a sign of earnings management(Mikova, 2014; Phillips et al., 2003). Many multinational companies try to reduce their tax liability by shifting profit through transfer pricing in order to reduce the overall tax liability for the corporation. For instance, multinational companies as Apple, Cisco, Devon, Google, Microsoft, Oracle and Pfizer had total profit equal 164 billion dollars, however, through TP, their tax rate was 12 percent(Mikova, 2014). TP and earnings management are considered related to each other. Both of them can affect the book income and taxable income. TP try to increase revenue and decrease costs which affect cash from operating activities. This will result in an increase of firm profit and hence increase tax. As a result, some managers try to use earnings management techniques to reduce taxes as much as possible.

Recent studies investigating earnings management via TP find evidence of earnings manipulation. For instance, Frank, Lynch, and Rego (2009) find a strong positive relationship between aggressive tax management and earnings management. They claim that disagreement between tax rules and financial accounting standards open the door for managers to manipulate earnings upwards while reducing taxable income in the same accounting period. Previous research support unified accounting standards for both financial and tax reporting. They claim that this will reduce the opportunistic behavior of the managers and the tax authority can control reported earnings(Desai \& Dharmapala, 2009; Mikova, 2014). Previous research suggests that financial income may be used as a basis for taxation as managers can manipulate financial income without affecting 
taxable income(Manzon Jr \& Plesko, 2001; Phillips et al., 2003). Using a sample of 600 U.S corporations, Graham, Hanlon, and Shevlin (2011) find that 31 percent of the surveyed firms use TP strategies to manipulate earnings.

On the other hand, The study done by Widiatmoko and Mayangsari (2016) find that $\mathrm{TP}$ has an insignificant positive effect on earnings management. In addition, Noviana Mulyani and Dewi (2018) find that TP has no effect on earnings management. They claim that TP is used to regulate and reduce tax obligations for the interest of the firm's stakeholders and not to violate the applicable laws. Based on the above literature, the following hypothesis is formulated as follows.

H1: Tax planning significantly affects earnings management practices.

$\mathrm{H} 2$ : Net deferred tax liabilities significantly affect earnings management practices.

H3: Net deferred tax liabilities mediate the relationship between tax planning and earnings management practices.

\section{Methodology}

This section describes the sample, the study variables, and presents the models used to analyze how the firm's TP and NDTL influence its earnings quality.

\subsection{Sample and Data Collection}

A multi-sector sample of 127 publicly listed firms in the Egyptian stock exchange was used for analysis. The sample period covers the years 2012 to 2018 for 889 observations. Stratified simple random sampling was used to select the studied sample. Path analysis was employed in this study. The financial data was extracted from annual reports which were sourced from Thomson Reuters Eikon database which is considered an important global database of financial data(Gallego-Álvarez, Lozano, \& Rodríguez-Rosa, 2018). The study adopts three basic sample selection criteria in order to achieve results for analysis. First of all, firms with missing financial data (probably as a result of insufficient data) needed for this study for the period are eliminated. Also, banks and financial institutions are not included. Lastly, a stratified simple random sample was employed to select the firms used in this study. The final sample yields 889 observations from different sectors. Table 2 displays the sample breakdown. 
Table 2: Economic Sector Breakdown

\begin{tabular}{|l|r|r|}
\hline & \multicolumn{2}{|c|}{$\begin{array}{c}\text { Number of } \\
\text { observations }\end{array}$} \\
\hline Basic Materials & 259 & 29.1 \\
\hline Consumer Cyclicals & 231 & 26.0 \\
\hline Consumer Non-Cyclicals & 224 & 25.2 \\
\hline Industrials & 175 & 19.7 \\
\hline Total & 889 & 100.0 \\
\hline
\end{tabular}

\subsection{Study Variables}

\subsubsection{Dependent Variable}

This study investigates the impact of TP and NDTL on firms' earnings management (EM), the dependent variable. Several studies on earnings management use accruals as a proxy of earnings management (Badertscher et al., 2006; P. M. Dechow, Sloan, \& Sweeney, 1995; Guay, Kothari, \& Watts, 1996; Healy \& Wahlen, 1999; R. Md Noor, N. Mastuki, \& Z. Aziz, 2007; Puspitasari \& Muktiyanto, 2018). For the current investigation, discretionary accruals are used as a proxy for earnings management. It is calculated using the modified-Jones model as proposed by P. M. Dechow et al. (1995). The model for discretionary accruals is estimated by every year and industry which require at least 15 observations for each industry-year grouping and this condition was met in the selected sample. The discretionary accruals are calculated by measuring the nondiscretionary accruals as a portion of the total accruals in the Modified Jones Model using three steps. First, the total accruals were calculated as follow:

$$
T A C C_{t}=\Delta C A_{t}-\Delta C a s h-\Delta C L_{t}+\Delta D C L_{t}-D E P_{t}
$$

Where $\mathrm{TACC}_{\mathrm{t}}$ is the total accruals in year $\mathrm{t} ; \Delta \mathrm{CA}_{\mathrm{t}}$ is the change in current assets in year $\mathrm{t} ; \Delta \mathrm{Cash}$ is the change in cash and cash equivalents in year; $\Delta \mathrm{CL}_{\mathrm{t}}$ is the Change in current liabilities in year $t ; \Delta \mathrm{DCL}_{t}$ is the change in short term debt included in current liabilities in year $\mathrm{t}$; and $\mathrm{DEP}_{\mathrm{t}}$ is the depreciation and amortization expense in year $t$.

Second, the total accruals which are the sum of nondiscretionary accrual and discretionary accruals are formulated using the modified jones model as shown below:

$$
\frac{T A C C_{t}}{A_{t-1}}=\alpha_{1} \frac{1}{A_{t-1}}+\alpha_{2} \frac{\left(\Delta R E V_{t}-\Delta R E C_{t}\right)}{A_{t-1}}+\alpha_{3} \frac{P P E_{t}}{A_{t-1}}+\varepsilon_{t}
$$


Where $\mathrm{TACC}_{\mathrm{t}}$ is total accruals in year $\mathrm{t}$ divided by total assets in year $\mathrm{t}-1, \Delta \mathrm{REV} \mathrm{V}_{\mathrm{t}}$ is revenues in year $t$ less revenues in year $t-1 ; \triangle R E C$ receivables in year $t$ less receivables in year $\mathrm{t}-1 ; \mathrm{PPE}_{\mathrm{t}}$ is the Gross property plant and equipment in year $\mathrm{t}$; $\mathrm{A}_{\mathrm{t}-1}$ is total assets in year $\mathrm{t}-1$; and $\alpha_{1}, \alpha_{2}$, and $\alpha_{3}$ are Parameters to be estimated, namely alphas which are estimated by means of an ordinary least squares regression (OLS).

Finally, the discretionary accruals is calculated which is the residual of Eq. 2. The absolute value of the residual is used as a proxy for earnings management.

\subsubsection{Independent Variables}

This study uses two independent variables, namely: TP and net deferred tax liabilities. In addition to four control variables, namely: Firm size, liquidity, leverage and earnings per share.

(1) Tax planning (TP) used in this study is computed using a tax retention rate (TRR) which evaluates the effectiveness of tax management on firms' financial reporting. It is suggested that

TRR provides an appropriate measure for TP effectiveness (Wild, Subramanyam, $\&$ Halsey, 2005). It is computed by dividing net income for firm $i$ in year $t$ by net income before tax for firm i in year t- 1 . The size of the effectiveness of tax management represents the effectiveness of TP.

(2) Net Deferred Tax Liabilities(NDTL) used in this study arises from the temporary differences between book and taxable income. It is calculated using the below formula as used in Phillips et al. (2003):

$N D T L_{t}=\frac{\left(\mathrm{DTA}_{t}-D T L_{t}\right)}{A_{t-1}}$

Where DTA $A_{t}$ is the deferred tax assets in year $t, D T L_{t}$ is the deferred tax liabilities in year $\mathrm{t}$; and $\mathrm{A}_{\mathrm{t}-1}$ is total assets in year $\mathrm{t}-1$.

(3) This study uses four control variables. First, firm size(SIZE) measured as the natural log of firm total assets. Second, leverage(LEV), measure as total debt to total equity. Third, liquidity(LIQ) measured as current assets divided by current liabilities. Finally, firm performance(Perf) measured using market-based measures, earnings per share(EPS) which is calculated by dividing total earnings by outstanding shares.

\subsection{Path Analysis Model}

To analyze the indirect effects of NDTL on earnings management, a path analysis was conducted. As shown in Figure 1, the model proposes a mediating 
impact from NDTL for the association between TP and EM. In addition, the direct effect of TP on EM is investigated. This study employs path analysis using IBM Analysis of Moment Structures (AMOS) for data analysis. It is appropriate for analyzing a series of interrelated dependence relationship simultaneously which helps in testing the fit between the model and the data. It compares simultaneously regression coefficients, means, and variances(Ghof Ar \& Isl Am, 2015).

Figure 1: Proposed Framework

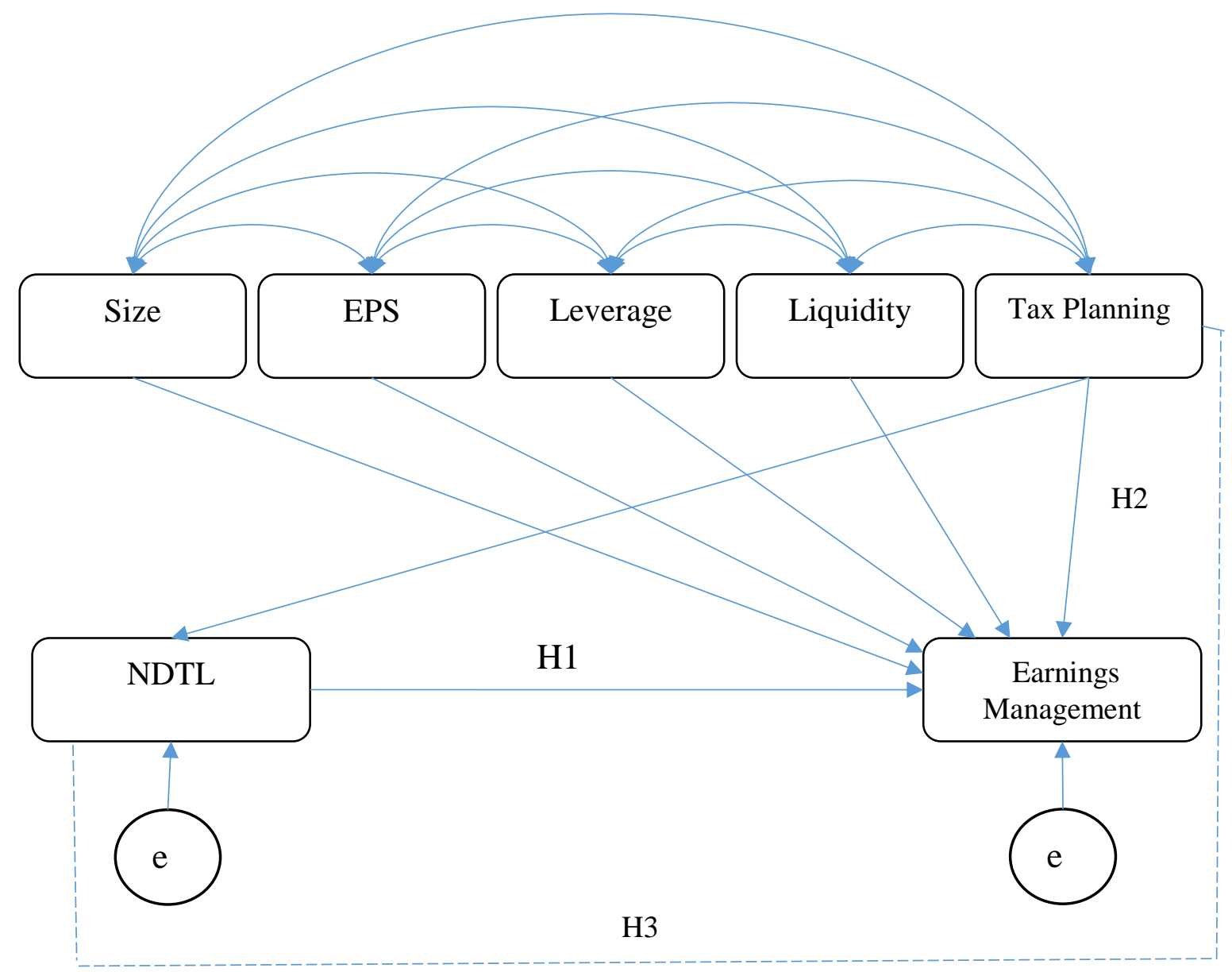

\section{Results and discussion}

\subsection{Descriptive statistics}

Table 3 presents the descriptive statistics where the standard deviation values range from 0.01 to 10.31, which show a widespread around the mean. In addition, the mean values of all variables ranged from -0.0013 to 8.827. However, the analyses of skewness and kurtosis indicate the normality of the study variables. The values were inside the adequate ranges for normality where kurtosis range from -2.0 to +2.0 and 
skewness range from -1.0 to +1.0 for every study variable(Byrne, 2016). For conducting path analysis, the used maximum likelihood estimators require multivariate normality of the data or distorted results will be produced.

Table 3: Descriptive Statistics

\begin{tabular}{|l|l|l|l|l|l|l|c|}
\hline & $\mathrm{N}$ & Mean & $\begin{array}{c}\text { Std. } \\
\text { Deviation }\end{array}$ & \multicolumn{2}{c|}{ Skewness } & \multicolumn{2}{c|}{ Kurtosis } \\
\cline { 2 - 8 } & Statistic & Statistic & Statistic & Statistic & $\begin{array}{c}\text { Std. } \\
\text { Error }\end{array}$ & Statistic & $\begin{array}{c}\text { Std. } \\
\text { Error }\end{array}$ \\
\hline EM & 889 & .0825 & .09218 & .018 & .082 & -.097 & .164 \\
\hline NDTL & 889 & .0158 & .02315 & -.145 & .082 & -.041 & .164 \\
\hline TP & 889 & -.0013 & .01058 & .023 & .082 & -.221 & .164 \\
\hline Size & 889 & 8.8274 & .69816 & .210 & .082 & -.534 & .164 \\
\hline Liquidity & 889 & 2.9789 & 8.15227 & .018 & .082 & -.163 & .164 \\
\hline EPS & 889 & 1.3719 & 6.15444 & -.002 & .082 & -.141 & .164 \\
\hline Leverage & 889 & 1.5434 & 10.31726 & .207 & .082 & -.483 & .164 \\
\hline
\end{tabular}

\subsection{Path Analysis}

Before using path analysis, the correlation between variables in the model was tested. Table 4 shows the correlation analysis between earnings management and the predictors. A significant correlations between EM and both NDTL and TP is shown, with the strongest correlation being between EM and NDTL. The correlations between NDTL and all study variables were significant. Similarly, a significant correlation between TP and all study variables is shown. The Chisquare tests displayed in table 4 reveals that null the hypothesis cannot be rejected. This implies that the proposed model fits the data as well as the saturated model. All study variables when analyzed simultaneously, predicted $11 \%$ of firm EM.

Table 5 presents the model fit index which assesses the overall proposed model fit. The Normed Fit Index (NFI), the ratio between Chi-squared test $\left(\chi^{2}\right)$ and degrees of freedom (df) (CMIN/DF), the Relative Fit Index (RFI), the Incremental Fit Indexes which are based on predicting the comparison of the proposed model with the null model, in which one general factor is estimated to satisfy all the measured variables(IFI), the Comparative Fit Index (CFI), the Tucker-Lewis Fit Index (TLI), and Root Mean Square Error of Approximation (RMSEA) were drawn as illustrated in table 5. The model indices were found to be within their acceptable level as such $\mathrm{CMIN} / \mathrm{DF}=0.061$, RMSEA $=0.000 \mathrm{CFI}=$ $1, \mathrm{NFI}=1, \mathrm{RFI}=0.999, \mathrm{IFI}=1.001$ and $\mathrm{TLI}=1.019$. Thus, suggesting that path analysis adequately fit the data. Therefore, the investigation could proceed to test the hypothesized relationships. 
Table 4:Correlation, squared multiple correlation, and Chi Square

\begin{tabular}{|c|c|c|c|c|c|c|c|c|}
\hline & EM & NDTL & TP & Size & Liquidity & EPS & Leverage & $\begin{array}{c}\text { Squared } \\
\text { Multiple } \\
\text { Correlations }\end{array}$ \\
\hline EM & 1 & & & & & & & .110 \\
\hline NDTL & $-.205^{* *}$ & 1 & & & & & & - \\
\hline $\mathbf{T P}$ & $-.077^{*}$ & $-.077^{*}$ & 1 & & & & & - \\
\hline Size & $-.126^{* *}$ & $.185^{* *}$ & $.103^{* *}$ & 1 & & & & - \\
\hline Liquidity & -.038 & $-.131^{* *}$ & $.373^{* *}$ & $-.293^{* *}$ & 1 & & & - \\
\hline EPS & -.011 & $.084^{*}$ & $.450^{* * *}$ & $217^{* *}$ & $.166^{* * *}$ & 1 & & - \\
\hline Leverage & .001 & $.104^{* *}$ & $-.284^{* *}$ & $.350^{* *}$ & $-.572^{* *}$ & $.218^{* *}$ & 1 & - \\
\hline
\end{tabular}

Table 5 presents the unstandardized regression coefficients as well as the goodness of fit indices. The unstandardized regression coefficients are estimated by maximum likelihood (ML) methods. ML attempts to maximize the likelihood that the estimated values of the variables are correct. It was suggested that both TP and NDTL significantly affect EM measured by non-discretionary accruals (H1 and $\mathrm{H} 2$ ). In addition, NDTL mediates the relationship between TP and EM (H3). The results in table 5 do not support $\mathrm{H} 1$. That is, the results show an insignificant relationship between TP and EM ( $p>0.05)$. A possible explanation for this finding is that firms use TP to regulate tax burden without violating the law. The results of this study are in line with the results of Widiatmoko and Mayangsari (2016) and Noviana Mulyani and Dewi (2018) who find that TP has an insignificant effect on earnings management. They claim that TP is used to regulate and reduce tax obligations for the interest of the firm's stakeholders and not to violate the applicable laws. However, the results of this study are inconsistent with the study conducted by Frank et al. (2009) who claim that disagreement between tax rules and financial accounting standards open the door for managers to manipulate earnings upwards while reducing taxable income in the same accounting period.

On the other hand, the relationship between NDTL and EM is statistically significant $(\mathrm{p}<0.05)$ which support $\mathrm{H} 2$. Differences in accounting income under EAS and tax law motivate management to manipulate earnings. This highlights the importance of applying an adequate monitoring system on deferred tax and the disclosure requirement. The result is in line with the results of several studies such as Phillips et al. (2003), Blaylock et al. (2015), and Nabil(2016) who support the argument that NDTL may be considered as a motivator to earning management to reduce tax shelter and avoid losses. This is consistent with both agency theory and positive accounting theory. However, the results are in contradiction with the empirical findings of Trisnawati and Nugraheni (2015) 
and Widiatmoko and Mayangsari (2016) who showed that the deferred tax expense has an insignificant effect on earnings management.

Table 5: Path Analysis Results

\begin{tabular}{|c|c|c|c|c|}
\hline $\begin{array}{l}\text { Regression } \\
\text { Coefficients }\end{array}$ & $\begin{array}{l}\text { Estimat } \\
\text { e }\end{array}$ & $\begin{array}{l}\text { Model Fit } \\
\text { Index }\end{array}$ & $\begin{array}{c}\text { Default } \\
\text { Model }\end{array}$ & Acceptable Level \\
\hline $\mathrm{TP} \rightarrow \mathrm{NDTL}$ & $-.270^{* * *}$ & $\underset{\#}{\mathrm{CMIN} / \mathrm{DF}}$ & .061 & Less than 5 \\
\hline $\mathrm{TP} \rightarrow \mathrm{EM}$ & -.646 & $\mathrm{RMSE}^{\#}$ & .000 & $\begin{array}{l}\text { Less than } 0.05 \text { indicate a } \\
\text { close fit of the model }\end{array}$ \\
\hline $\mathrm{NDTL} \rightarrow \mathrm{EM}$ & $-.406 * *$ & $\mathrm{CFI}^{\#}$ & 1.000 & Greater than 0.95 \\
\hline Liquidity $\rightarrow$ EM & -.001 & $\mathrm{NFI}^{\#}$ & 1.000 & Greater than 0.9. \\
\hline Leverage $\rightarrow$ EM & .000 & $\mathrm{RFI}^{\#}$ & 0.999 & $\begin{array}{l}\text { Close to } 1 \text { indicate a very } \\
\text { good fit }\end{array}$ \\
\hline $\mathrm{SIZE} \rightarrow \mathrm{EM}$ & $-.019 * *$ & $\mathrm{IFI}^{\#}$ & 1.001 & $\begin{array}{l}\text { Close to } 1 \text { indicate a very } \\
\text { good fit }\end{array}$ \\
\hline EPS $\rightarrow$ EM & $.001 *$ & TLI $^{\#}$ & 1.019 & TLI greater than 0.95 \\
\hline \multicolumn{5}{|c|}{$\begin{array}{l}*{ }^{* *} \text { Indicate significance correlation at the } 0.05 \text { level (2-tailed).and } 0.01 \text { level, } \\
\text { respectively. } \\
\text { \#Source: Holmes-Smith, Coote, and Cunningham (2006) }\end{array}$} \\
\hline
\end{tabular}

Table 6 displays the mediating analysis using direct and indirect effect. It presents the direct and indirect effect of TP on EM. The results show that TP significantly influences EM through a mediator NDTL, where the indirect effect of TP on EM is significant at the 0.01 level, i.e., the increase in the value of TP by one unit leads to an increase in EM by 0.109 through the mediator NDTL. Moreover, both the direct and total effect of TP on EM is statistically insignificant which indicates the important role that NDTL plays in earnings manipulation. This result supports $\mathrm{H} 3$, which suggest that NDTL mediates the relationship between TP and EM. Moreover, the direct effect of NDTL on EM is statistically significant where the increase in the value of NDTL by one unit affect EM by 0.406 . Similarly, the direct effect of firm size on EM is statistically significant where the increase in the value of NDTL by one unit affect EM by 0.406 . This shows that the EAS 24 that regulates the firm's deferred tax does not prevent earnings management through TP and more disclosure may be required by the Egyptian firms. 
Table 6: Effect coefficients for the path model

\begin{tabular}{|l|l|l|l|}
\hline Variables & Direct Effect & Indirect Effect & Total \\
\hline TP ---> NDTL & $-.270^{* *}$ & - & $-.270^{* *}$ \\
\hline NDTL ---> EM & $-.406^{* *}$ & - & $-.406^{* *}$ \\
\hline TP ---> EM & -.646 & $.109^{* *}$ & -.536 \\
\hline SIZE --> EM & $-.019^{* *}$ & - & $-.019^{* *}$ \\
\hline Leverage $--->$ EM & .000 & - & .000 \\
\hline Liquidity ---> EM & -.001 & - & -.001 \\
\hline EPS ---> EM & .001 & .001 \\
\hline ** Indicate significance correlation at the 0.01 level (2-tailed). \\
\hline
\end{tabular}

\section{Conclusion}

This study analyses the context of the Egyptian listed firm to investigate whether TP and NDTL are used to manipulate earnings. In addition, the mediating role of NDTL between TP and EM was investigated. The results bring evidence that publicly listed firms minimize tax payments through TP using NDTL to manipulate earnings. However, the results do not support that TP has a direct effect on EM. The study results provide an alert to the tax authority, auditors and stakeholders due to the close correlation between NDTL, TP, and reported earnings which may be taken into consideration in their analysis and policy advising activities. This study contributes to EM literature and provides new evidence about variables that may induce earnings management practices of Egyptian listed firms.

The results support agency and positive accounting theory in which managers may use earnings management practices to affect reported earnings through NDTL to recognize income or expense to shift the earnings to avoid taxes. Some of the limitations of this study should be mentioned. First, the study excluded banks and financial institutions. Future studies may investigate these economic sectors. Second, only one mediator was studied. Future studies may involve other mediators that can affect the relationship between TP and earnings management. Third, only one measure for earnings management was used. Future studies may incorporate more measures as real based earnings management.

\section{Acknowledgement}

The author gratefully acknowledge the helpful comments of Dr. Baz Fawzy Kabil, General Director in the Egyptian Tax Authority, which substantially improved the article. All errors are our own. In addition, this paper was presented in the $27^{\text {th }}$ International Conference, Faculty of Commerce, Mansoura University, March 2019. 


\section{References}

Badertscher, B., Phillips, J., Pincus, M., \& Rego, S. O. (2006). Is deferred tax expense useful in detecting earnings management in earnings restatements. Retrieved from

Bernard, V. L., Skinner, D. J. J. J. o. A., \& Economics. (1996). What motivates managers' choice of discretionary accruals? , 22(1-3), 313-325.

Blaylock, B., Gaertner, F., \& Shevlin, T. (2015). The association between booktax conformity and earnings management. Review of Accounting Studies, 20(1), 141-172.

Brummer, S. (2017). Book-tax differences as a proxy for tax-induced earnings management-Evidence from Finnish private firms (Available on Internet).

Byrne, B. M. (2016). Structural equation modeling with AMOS: Basic concepts, applications, and programming: Routledge.

Chang, C., Herbohn, K., \& Tutticci, I. (2009). Market's perception of deferred tax accruals. Accounting \& Finance, 49(4), 645-673.

Dechow, P. M., Sloan, R. G., \& Sweeney, A. P. (1995). Detecting earnings management. Accounting review, 193-225.

Dechow, P. M. J. J. o. a., \& economics. (1994). Accounting earnings and cash flows as measures of firm performance: The role of accounting accruals. 18(1), 3-42.

Desai, M. A., \& Dharmapala, D. J. N. T. J. (2009). Earnings management, corporate tax shelters, and book-tax alignment. 169-186.

Ebrahim, A. M. (2014). IFRS Compliance and Audit Quality in Developing Countries: The Case of Income Tax Accounting in Egypt.

Elassal, M. M. (2012). The effect of the recogition for the deferred tax assets on earnings management. $C U$ Theses.

Frank, M. M., Lynch, L. J., \& Rego, S. O. J. T. A. R. (2009). Tax reporting aggressiveness and its relation to aggressive financial reporting. 84(2), 467-496.

Gallego-Álvarez, I., Lozano, M. B., \& Rodríguez-Rosa, M. (2018). An analysis of the environmental information in international companies according to the new GRI standards. Journal of cleaner production, 182, 57-66.

Gaynor, L. M., Kelton, A. S., Mercer, M., Yohn, T. L. J. A. A. J. o. P., \& Theory. (2016). Understanding the relation between financial reporting quality and audit quality. 35(4), 1-22. 
Ghof Ar, A., \& Isl Am, S. (2015). Corporate governance and contingency theory: Springer.

Graham, J. R., Hanlon, M., \& Shevlin, T. J. J. o. A. R. (2011). Real effects of accounting rules: Evidence from multinational firms' investment location and profit repatriation decisions. 49(1), 137-185.

Guay, W. R., Kothari, S., \& Watts, R. L. (1996). A market-based evaluation of discretionary accrual models. Journal of accounting research, 83-105.

Habanec, P., \& Bohušová, H. (2017). Comparison of Deferred Tax Materiality Reporting in Accordance with Continental and Anglo-Saxon Reporting System. Acta Universitatis Agriculturae et Silviculturae Mendelianae Brunensis, 65(6), 1917-1924.

Hanlon, M., \& Heitzman, S. (2010). A review of tax research. Journal of accounting and Economics, 50(2-3), 127-178.

Healy, P. M., \& Wahlen, J. M. J. A. h. (1999). A review of the earnings management literature and its implications for standard setting. 13(4), 365-383.

Holmes-Smith, P., Coote, L., \& Cunningham, E. (2006). Structural equation modeling: From the fundamentals to advanced topics. Melbourne: Sreams.

Ifada, L. M., \& Wulandari, N. (2015). THE EFFECT OF DEFERRED TAX AND TAX PLANNING TOWARD EARNINGS MANAGEMENT PRACTICE: AN EMPIRICAL STUDY ON NON MANUFACTURING COMPANIES LISTED IN INDONESIA STOCK EXCHANGE IN THE PERIOD OF 20082012. International Journal of Organizational Innovation, 8(1).

Kusumaningrat, M. R. A. (2017). Effect of Tax Deferred Charges, Leverage and Size of Management Company Earnings. Research Journal of Finance and Accounting, 8(12), 93-104.

Lee, B. B., Vetter, W., Williams, M. J. A., \& Research, F. (2015). Book-tax income differences and major determining factors. 4(3), 55.

Manzon Jr, G. B., \& Plesko, G. A. J. T. L. R. (2001). The relation between financial and tax reporting measures of income. 55, 175.

Md Noor, R., Mastuki, N., \& Aziz, Z. (2007). EARNINGS MANAGEMENT AND DEFERRED TAX. Malaysian Accounting Review, 6(1).

Md Noor, R., Mastuki, N., \& Aziz, Z. J. M. A. R. (2007). EARNINGS MANAGEMENT AND DEFERRED TAX. 6(1).

Mikova, S. J. a. T. (2014). Earnings Management Focused on Tax Plannin. Paper presented at the 4 "ANNUAL INTERNATIONA L CONFERENC E, Phuket, Thailand 
Mulyadi, M. S., Anwar, Y. J. P.-S., \& Sciences, B. (2015). Corporate governance, earnings management and tax management. 177, 363-366.

Noviana Mulyani, K. H. T., \& Dewi, R. R. (2018). The Effect of Tax Planning and Deferred Tax Expense on Earnings Management on Manufacturing Companies Listed In The Indonesia Stock Exchange. Paper presented at the PROCEEDING ICTESS (Internasional Conference on Technology, Education and Social Sciences).

Phillips, J., Pincus, M., \& Rego, S. O. J. T. A. R. (2003). Earnings management: New evidence based on deferred tax expense. 78(2), 491-521.

Puspitasari, S., \& Muktiyanto, A. (2018). Earnings Management, Effective Tax Rate (ETR) and Book-Tax Gap (BTG).

Rathke, A. A., Rezende, A. J., Antônio, R. M., \& de Moraes, M. B. M. (2017). Earnings Management Through Deferred Taxes in Brazil.

Rehman, M. U. (2017). Dynamics of Co-movements among Implied Volatility, Policy Uncertainty and Market Performance. Global Business Review, 18(6), 1478-1487.

Tang, T. Y. (2005). Book-tax differences, a proxy for earnings management and tax management-empirical evidence from China.

Trisnawati, R., \& Nugraheni, D. (2015). The Analysis Of Information Asymmetry, Profitability, And Deferred Tax Expense On Integrated Earning Management. South East Asia Journal of Contemporary Business, Economics and Law, 7(1), 17-24.

Walker, M. J. A., \& Research, B. (2013). How far can we trust earnings numbers? What research tells us about earnings management. 43(4), 445-481.

Wang, Y., Butterfield, S., \& Campbell, M. J. I. M. R. (2016). Deferred tax items as earnings management indicators. 12(2), 37-42.

Warsono. (2017). Deferred Tax Assets and Deferred Tax Expense

Against Tax Planning Profit Management. Shirkah: Journal of Economics and Business, 2(2), 199-214.

Watts, R., \& Zimmerman, J. (1986). Positive accounting theory.

Widiatmoko, J., \& Mayangsari, I. (2016). The Impact of Deferred Tax Assets, Discretionary Accrual, Leverage, Company Size and Tax Planning Onearnings Management Practices. Jurnal Dinamika Manajemen, 7(1), 22-31.

Wild, J. J., Subramanyam, K., \& Halsey, R. F. (2005). Financial Statement Analysis (Analisis Laporan Keuangan). Buku Satu. Edisi kedelapan. Salemba Empat. Jakarta. 


\section{Arabic References}

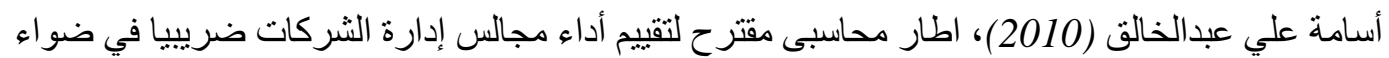

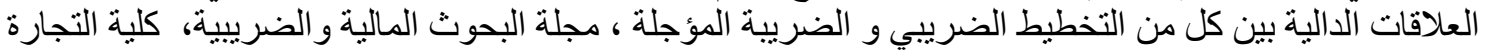

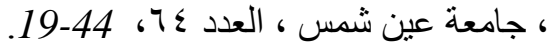
سمير سعد مرقص (2017)، التخطيط الضريبى : المبادئ و الأسس و التطبيقات المحلية و الدولية ــ الجزء الاول ،

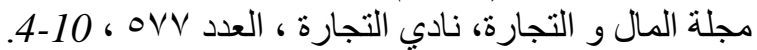

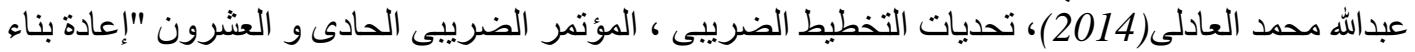

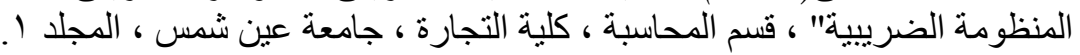

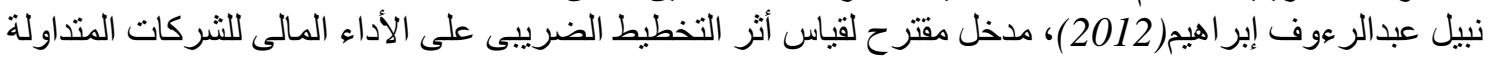
فى سوق المال المصرى - در اسة اختبارية ، مجلة المحاسبة المصرية ، كلية التجارة ، جامعة القاهرة ، العدد 7 ،

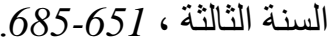
نبيل عبدالرعوف إبر اهيم(65) (2016)، فروق ضريبة الدخل الدفترية ـ مقياس جديد لإدارة الأرباح : در اسة تطبيقية ،

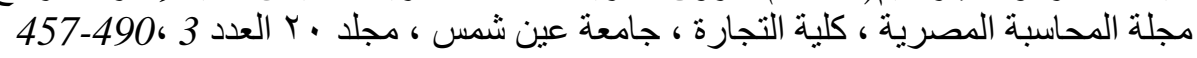

